\title{
INFLUENCE OF THE PROFESSIONAL ENGLISH LANGUAGE TEACHING QUALITY ON THE ACHIEVEMENTS OF A SUBJECT STUDY BY MEDICAL STUDENTS
}

\author{
Н. І. Єлагіна, Н. О. Федчишин
}

Тернопільський національний медичний університет імені І. Я. Горбачевського МОЗ Украӥни

\section{ВПЛИВ ЯКОСТІ ВИКЛАДАННЯ АНГЛІЙСЬКОЇ МОВИ ЗА ПРОФЕСІЙНИМ СПРЯМУВАННЯМ НА РЕЗУЛЬТАТИ ВИВЧЕННЯ ПРЕДМЕТА СТУДЕНТАМИ-МЕДИКАМИ}

\begin{abstract}
The article analyzes some aspects of the influence of a teacher's personality on the formation and development of students' academic performance. The relevance of the study of personal qualities of a teacher as a guarantee of high-quality mastering of Professional English by medical students is justified in the article. On the background of this thematic area of theoretical and scientific concerns, our study tackles and develops specific aspects of the influence of the teaching skills on the quality of the content and objectives of Professional English language teaching in a medical institution of higher education. The article deals with the approaches of modern researchers to the professional activity of a teacher in a higher educational institution and presents a psychological perspective of the problem, taking into account the components of high-quality education. The involvement of the academics in the complex activities specific to higher medical educational process places the act of teaching Professional English among the defining priorities of meeting quality, national and international standards of academic medical education. As a defining activity aimed at the enhancement of the teachers' competencies, teaching Professional English is a priority and decisive value across all the other disciplines which contribute to achieving the quality of higher medical education, being, in fact, the central intercultural core that provides substance, consistency and strength to the intercultural dimension of the academic medical education.
\end{abstract}

Key words: teaching quality; achievements of a subject study; the Professional English language; medical students.

Анотація. У статті аналізуються деякі аспекти впливу особистості викладача на формування і розвиток успішності студентів. У статті обгрунтовується актуальність вивчення особистісних якостей викладача як гарантії якісного оволодіння англійською мовою за професійним спрямуванням студентами-медиками. У дослідженні розкриваються специфічні аспекти впливу педагогічної майстерності на якість змісту і цілі навчання англійської мови за професійним спрямуванням у медичному вузі. У статті розглядаються підходи сучасних дослідників до професійної діяльності викладача у вищому навчальному закладі та представлений психологічний ракурс проблеми з урахуванням компонентів якісної освіти. Аналіз питань діяльності викладача, характерної для вищого медичного освітнього процесу, ставить навчання англійської мови за професійним спрямуванням у число визначальних пріоритетів відповідності якості, національним і міжнародним стандартам медичної освіти. Доведено, що педагогічна діяльність спрямована на підвищення компетентності викладачів. Викладання англійської мови за професійним спрямуванням $є$ пріоритетною складовою серед інших дисциплін, що сприяють досягненню якості вищої медичної освіти, будучи, по суті, центральним міжкультурним ядром, що забезпечує зміст, послідовність і міцність міжкультурного виміру медичної освіти.

Ключові слова: якість викладання предмета; результати навчання; англійська мова за професійним спрямуванням; студенти-медики.

Introduction. In the context of Ukraine's integration into the international scientific and educational space,

(c) N. I. Yelahina, N. O. Fedchyshyn the study and teaching of foreign languages, and especially English - the language of international communication, is not just a component of fundamental 
education, but becomes one of the key factors to meeting such requirements of the Bologna Process as expanding the mobility of students and other personnel for mutual enrichment of European experience; increasing the competitiveness of graduates in the domestic, European and world labor markets.

Improving the quality of a foreign language teaching in higher medical educational institutions should be provided with motivation, the purpose of which is to increase interest in obtaining knowledge, as opposed to obtaining a diploma, through explanatory work on the role of a foreign language proficiency in strengthening the competitiveness and mobility of graduates and students and on the principles of the Bologna convention, the introduction of incentive measures by the management body of faculties and institutes, etc.

In many Western countries, the assessment of a teacher's activity is carried out in such three areas as: the organizational and methodological aspect of conducting classes; the level of development of communicative culture; the presence of professionally important personality traits that ensure the effectiveness of the behavioral side of the teacher's activity and their relationships with students $[3,4,5,10]$.

Teacher quality is widely believed to be important for education, despite little evidence that teachers' credentials matter for student achievement. This analysis reviews a wide range of empirical studies that examine the impact of teacher characteristics on teacher effectiveness in order to draw conclusions about the extent to which these characteristics are, in fact, linked with teacher performance. For example, developing an approach to policy that values different and multiple teacher characteristics based on the research evidence may prove promising. It is important to note that many personal characteristics important for a good teacher are not measured in the studies reviewed. Various aspects of the quality teaching in the educational process were studied by scientists (V. Abrosimova, M. Burova, R. G. Berns, K. S. Cockrell, P. M. Erickson, N. Fedchyshyn, I. Zimniia, Yu. Lihum, O. Sydorenko, H. Skok, A. Vykhrushch, R. Wootten S. Yaremchuk, N. Yelahina, etc.).

Considered as a process, learning and improving English knowledge represents a constant and harmonious alternation of teaching, learning and assessment, activities that are interacting in an organic, dialectic manner, so we can talk about the triangular paradigm of teaching-learning-assessment. According to the same coordinates, the education and training of medical students in terms of English language skills becomes a process of adjustment and tuning, which completes the activities, objectives and content of teaching and learning and puts the bases of new requirements for the future teaching process.

The aim - to analyze the aspects of teacher background that can be translated into policy recommendations and incorporated into teaching practice.

Theoretical framework. The effectiveness of a teacher's performance is one of the most important factors, which, along with others, can significantly contribute to improving (or, conversely, reducing) the effectiveness of students' learning. Pedagogical creativity is a certain psychological and social readiness of the individual, which allows you to change the situation in such a way that the teacher and student can effectively interact, reach mutual understanding, reduce difficulties in communication, and solve conflicts. Pedagogical creativity implies that the teacher has a high level of interpersonal competence, since the interactive teaching mode at the present stage is provided, as is known, by such factors as: personal inclusion, dialogue communication with students and mutual creativity. The task of the teacher is to create a working atmosphere that would promote effective work. The individual and personal uniqueness of the student requires a separate, peculiar type of communication, so the teaching profession contains emotional activity, sympathy, and empathy. Important components of high-quality work include the ability of the teacher to share theoretical information accompanied with questions that are aimed at updating the student's knowledge and analyzing their life experience, the ability to arrange a discussion, etc. Nowadays, teachers use video materials, audio materials, slides in the classroom, especially these methods of work have a significant impact on the process of medical students training [12, p. 104].

There is no doubt that the performances obtained in the teaching of English depend on the quality of the work of the educator, activity that reveals his or her personality as a whole (as a unity system), but especially by specific teaching, scientific and management skills.

The framework for this study includes five broad categories of measurable and policy-relevant indicators to organize the teacher characteristics assumed to reflect teacher quality. It is notable that findings for these characteristics frequently differ for teachers and that the body of research on the subject of teacher quality suggests that the context of teaching matters 
(e.g., differences in grade levels, subject areas, and student populations). A refined understanding of how teacher attributes affect their performance across these different teaching contexts can be helpful in determining the range of potentially effective policy options [9, p. 14].

Teacher quality is a multidimensional construct that includes a range of variables, including teacher qualifications, teacher characteristics, teacher practices, and teacher effectiveness.

Teacher qualifications include many variables, such as subject-level knowledge, advanced degrees, certification exam scores, degree-granting institutions, certification, and content-based pedagogical knowledge. For content-area teachers, the qualifications of subject area expertise and pedagogical knowledge would seem theoretically to be of primary importance; however, little research has investigated the relation of these qualifications to student outcomes.

Teacher experience plays an important role in terms of a teacher quality. Several studies have found a positive effect of experience on teacher effectiveness; specifically, the "learning by doing" effect is most obvious in the early years of teaching. The pedagogical skills of a teacher can be divided into the following groups: gnostic skills - the ability to cognitive and analytical content; project skills - the ability to predict, create an object as a certain integrity in the imagination, determine the forecast of professional activity; constructive - the ability to create a real model of planned activities; communicative - the ability to communicate with students; organizational skills - the ability to implement an activity plan; creative skills.

An indispensable condition for the professional activity of a teacher of a higher educational institution is scientific activity and communication. The system of scientific communication and theoretical and practical study of issues that are within the scope of their research interests give the teacher knowledge about the circle of researchers of this problem, its critical analysis, available developments and create prerequisites for its deeper study. As you know, a teacher of a higher educational institution should use in the process of teaching students the conclusions of their own research activities, which requires much time, and, taking this into account, the teacher's ability to plan and organize such activities formed at the proper level [14, p. 157].

The issue of teacher personality from the perspective of its academic education dimension, a concern of many disciplines, lies further out in the field of controversy. Philosophers, psychologists, sociologists, and especially pedagogues are trying to substantiate interrogative approaches that aim at deciphering the instructional-educational meanings and significance of the personality of the teachers [11].

It was stated that "it is very difficult and it might be wrong to absolutize the specific psychological personality of the teacher. It would be more appropriate to speak of an optimum, of having the intellectual, practical and moral qualities the man is capable of" [7], and respectively, the teacher must display when teaching English.

We note that, in the field of literature, a specific set of "qualities" or "defining characteristics" is required, in order to ensure the achievement of quality and effective teaching (e.g.: solid specialized training, high qualification and professional competence, durable psycho-volitional structures, sound moral beliefs, selfcontrol and insight, emotional stability, decision and action capacity, fast adaptability under stress, specific balance between ideation and action, superior intelligence coupled with strong will and moral strength, very sharp sense of observation, "systematic analysis" as a particular skill, high capacity of representation and spatial thinking, realism doubled by imagination).

A modern teacher of higher education should take into account the following components of quality education: 1) the educational environment (it should be healthy, safe, provided with resources and favorable conditions; 2) the content of education, which is reflected in the relevant curricula and materials for mastering basic knowledge, acquisition of skills and abilities by students; 3 ) the teaching and educational process aimed at the development and formation of personality; 4) the results that relate to knowledge, skills, personal position and connected with national tasks in the field of education. The quality of education is determined by the social order and requirements for a graduate. The requirements of society reflect such characteristics of the quality of educational results as competence and motivation for continuing education and professional growth, that characterizes a modern educated personality [3, c. 22-23].

The success of teaching methods today depends on the psychological knowledge of the teacher, the level of their professionalism, and the ability to organize personality-oriented communication. So, for example, when planning each lesson of English, it is necessary to take into account how long students can maintain active attention, as well as to monitor the switching of students' attention from one type of activity to another. It's a very important issue while planning every lesson 
of English. Awareness of the teacher about the sociopsychological patterns of a group work, features of the organization of group activities and interaction of individuals in a group, socio-psychological determinants of group influence, as well as the ability to analyze interpersonal relationships in a particular study group allow them to significantly increase the effectiveness of training. The art of teaching is manifested primarily in the strength of their influence on the personality of each student and a group as a whole. The result of this influence is positive personal changes of future specialists. These changes start with a change in motivation. It is motivation that can trigger the activity of the individual. In turn, the person's activity increases the efficacy of their performance. Therefore, only a teacher who perfectly knows and loves both their profession and those they teach can foster students' interest in a professional honor and cause the need for perfect mastery of the future profession $[1,15]$.

In this context, the American researcher Rachel Wootten has quite interesting views on the modern teacher-innovator. Studying the features of an innovative educator, she draws attention to seven main characteristics of such an educator. Let's characterize them in detail: 1) reflection. It is extremely important for the teacher to be aware of what really works during classes and what doesn't. We pay special attention to the researcher's statement that even though it may be inconvenient, we must accept that even a very prepared lesson can be a failure. The researcher advises you to constantly analyze the processes and ideas that the teacher uses in order to be sure that they are the best for students; 2) constant training. The teacher is an innovator who is always studying; 3 ) creativity. Such a teacher is creative in thinking and approaches; 4) proximity to those whom he teaches. The teacher is aware of all the needs of their students and can determine what is best for each of them. Such a teacher is called a life-long learner, he always knows about changes in the educational sphere, as well as how to implement these changes in the process of learning; 5) cooperation with colleagues. An innovative teacher always cooperates with their colleagues, exchanges opinions and views on learning, discusses topical issues of improving the educational process; such a teacher always explores important topics together with their colleagues; 6) curiosity. The teacher always tries to improve themselves, carefully analyzes their professional performance; 7) adherence to principles. The teacher lives according to established values. Such a teacher is aware of their mission and does everything possible for high-quality training of their students. He worries about making firm decisions, even when they are not popular, someone does not like them. Such a teacher always defends their beliefs [16].

A modern teacher should be properly oriented in various branches of science, the basics of which he teaches, know its capabilities for solving socio-economic, industrial and cultural problems, as well as he must be aware of the results of new research, discoveries and hypotheses. It is extremely important to see the near and long-term prospects of the science that he teaches, to master the culture of scientific and pedagogical thinking.

We will focus in what follows on those aspects of teacher knowledge and abilities that are at the core of expert teacher competence and performance in language teaching. Competence is understood as "the technical skills and professional capabilities that a teacher needs to bring to a position in order to fulfill its functions completely" [6]. Consequently, practitioners of English language teaching must demonstrate at least four dimensions of teacher competency: language proficiency, content knowledge, teaching skills and professionalism [13].

Language proficiency is the ability of a teacher to comprehend the material to be taught, to provide a good language model, to maintain the use of the target language during the teaching process, to select target language resources in an appropriate manner, to give correct feedback, and to provide language enrichment experiences for the learners.

Content knowledge is a dimension concerning what a teacher knows about the language teaching itself. Typically, it consists of language analysis, learning theory, methodology and sometimes a teaching practicum. For example, it could encompass language teaching methods, second language acquisition, phonology and syntax, discourse analysis, critical applied linguistics and language theories etc. More concretely, teachers should actually demonstrate that they are able to: understand the learners' needs, diagnose strengths and weaknesses of the students' language performance, evaluate students' learning, select and design suitable learning tasks, make use of authentic materials and modern technology, evaluate their own teaching methods and techniques etc.

Teaching skills come as a direct application of the disciplinary or pedagogical content knowledge. If we see teaching as an act of performance, then we must conclude that a teacher should be able to carry himself or herself through the lesson, using a wide array of 
methods and techniques. Such routines and procedures include: opening the lesson, introducing and explaining tasks, setting up learning arrangements, checking students' understanding, guiding the students' practice, monitoring their performance, making transitions between tasks, ending the lesson.

From the perspective of teacher knowledge, teaching is not merely the application of cognition and of learnt skills. It is perceived as a much more complex process affected by the classroom context, the general and specific instructional objectives, the teachers' beliefs and values, the motivation of the learners, and the teachers' management skills.

An important dimension is also professionalism. Teaching is a profession, a career in the field of specialized education, requiring specialized training, obtained through both academic study and practical experience. Teachers of English should be in a continuous attempt to improve themselves, to achieve increasingly higher standards of English language teaching. They can do so by doing continuous research and by publishing papers in teacher magazines and journals, by participating in conferences and professional meetings. They must ceaselessly improve and demonstrate language proficiency as a component of professional certification [17].

The structure of the "crystallized personality" of the educator (as a configuration based on plasticity and flexibility) requires scientific, psychosocial and psychological competence [8]. The co-articulation of these three dimensions defines what might be called educational competence required and specific to the teaching activity. They also require abilities and skills in order to optimize human relations in the educational activity, the ability to positively influence the group of medical students as a whole, adapting to different roles. They must also demonstrate abilities to use authority in a balanced manner and effective communication skills.

We believe that on the basis of these afore mentioned competencies, the teachers, during their entire academic activity, can achieve the two major goals of higher medical education: on the one hand informing, transmitting knowledge, and on the other hand, forming, namely ensuring the optimal conditions for the development and improvement of the personality of the medical students. The teaching process cannot be limited merely to the simple chronological unfolding of moments, stages and sequences. It requires training and guiding groups of future physicians, providing all conditions necessary for every student to master the English language, according to his or her possibilities and social require- ments expressed by the ideal of the educational model, that of the doctor.

The act of teaching is to address the academic educational content in a realistic manner, to correlate it with real situations, with the cognitive and affective needs imposed by the profession of physician. A modern university teacher is not only, or primarily, a professor who uses the most advanced technologies, but a teacher who is very well informed, flexible and open-minded to new things, aware that their work has the mission to prepare medical students for their future role in the modern intercultural medical organization which they will be part of.

As a consequence, the teaching activity organized and carried out according to the contextual paradigm, helps the teacher associate the content taught to concrete situations, specific to the international medical environment in which the students will operate. Such scholars as Berns and Erickson explain teaching from the contextual perspective as an instructional innovation assisting students in using the contents learned in real situations where they can be implemented [7].

In order to achieve the quality and effectiveness of teaching, the teacher uses the whole system of psychopedagogical, scientific and praxeological competences, in terms of skills and attitudes, constantly tailoring the teaching act to the peculiarities of the medical students, the performance standards of teaching English and to the underlying and guiding rules. Hence appears the need for each university teacher to have these skills, to determine and to provide a differentiated conduct of the medical students through a specific way of approaching and working with them. It is equally important to ensure, during each teaching sequence, a quality intercultural medical education through promoting the higher values of the "discipline they teach, by using (appropriate) training methods and techniques" [2].

Conclusions and Prospects for Research. We can basically assert that the qualitative and effective teaching of English in the medical academic environment ranks the characteristic skills of a performant teacher at the base of the fundamental requirements that offers students basic knowledge and improvement of the English language at the level of national and international standards. The teacher must take into account the individual, age and gender characteristics of the students under the specific conditions of organizing educational activities in a modern university. Today, it is extremely important for a teacher to be able to form future specialists' readiness and desire for continuous self-education, constant professional 
self-improvement. Nowadays, approaches to the professional performance of a university teacher require constant improvement not only of professional competence, the components of which are professional (special), methodological and psychological training, but also the level of general cultural development. It is a professionally competent teacher of a higher

\section{List of literature}

1. Амбарцумова Ж. С. Психологическая культура преподавателя как важный фактор формирования успешности личности студента / Ж. С. Амбарцумова, О. В. Евдокимова // Личность - слово - социум : материалы VI Междунар. науч.-практ. конф. - Белорусский государственный экономический университет, 2006. - Режим доступа : http://pws-conf.ru/ nauchnaya/lss-2006/371-formirovanie-lichnosti-v-sociume/8175-psihologicheskaya-kultura-prepodavatelya-kakvajnyyfaktor-formirovaniya-uspeshnoy-lichnosti-studenta. html.

2. Бурова М. В. Слагаемые имиджа педагога [Электронный ресурс] / М. В. Бурова. - Режим доступа : http:// festival.1september.ru/articles/620720/.

3. Лігум Ю. С. Якість освіти і новітні технології навчання в контексті інтеграції в Європейський освітній простір / Ю. С. Лігум // Педагогіка і психологія. - 2011. № 2 (71). - С. 22-27.

4. Якість вищої медичної освіти (до 60-річчя ТДМУ) : монографія / [А. В. Вихрущ, І. М. Кліщ, Н. О. Федчишин та ін.] ; за ред. А. Г. Шульгая, Н. О. Федчишин. - Тернопіль : ТДМУ, 2017. - 482 с.

5. Якість університетської освіти: актуальні питання теорії і практики: колективна монографія / [А. В. Вихрущ, Н. І. Єлагіна, Г. І. Кліщ та ін.] ; відп. ред. Анатолій Вихрущ. - Тернопіль : ТНЕУ, 2016. - 525 с.

6. Aitken J. The Capable Teacher, Competency Framework for Teachers of English for Academic Purposes [Electronic resource] / J. Aitken. - Access mode : http://www.baleap.org. uk/media/uploads/pdfs/teap-competency-framework.pdf.

7. Berns R. G. Contextual Teaching and Learning: Preparing Students for the New Economy / R. G. Berns, P. M. Erickson // The Highlight Zone: Research@Work [Electronic resource]. - Access mode : www.cord.org.

8. Cockrell K. S. A Context for Learning: Collaborative Groups in the Problem-Based Learning Environment / K. S. Cockrell, J. A. Hughes // The Review of Higher Education. - 2000. - P. 357.

\section{References}

1. Ambarcumova, Zh.S., \& Evdokimova, O.V. (2006). Psihologicheskaja kultura prepodavatelja kak vazhnyj faktor formirovanija uspeshnosti lichnosti studenta [Psychological culture of the teacher as an important factor in the formation of success of the student's personality]. Lichnost-slovosocium: materialy VI Mezhdunar. nauch.-prakt. konf. - school who can optimize the educational process and introduce modern educational information technologies. Only such a teacher will be able to form those parameters of the socially adapted personality of the future specialist, thanks to which the individual will be able to constantly develop himself.

9. Fedchyshyn N. O. Peculiarities of future teacher's training at the higher educational establishment / N. O. Fedchyshyn, N. I. Yelahina // Медична освіта. - 2020. № 1 (86). - C. 11-15.

10. Fedchyshyn N. O. Quality of higher medical education in Germany: realities and pecualiarities / N. O. Fedchyshyn // Human studies: series of Pedagogy. - 2020. - Issue 11/43. P. 103-114.

11. Palmer P. J. The Courage to Teach: Exploring the Inner Landscape of a Teacher's Life [Electronic resource] / P. J. Palmer. - 10th anniversary edition. - Access mode : www.wou.edu/ girodm/library/palmer.pdf.

12. Prokop I. A. The use of English professional texts-related exercise set for developing communicative competence of medical students / I. A. Prokop // Медична освіта. - 2017. - № 4. - С. 101-106.

13. Richards J. C. Competence and Performance in Language Teaching / J. C. Richards. - New York, NY : Cambridge University Press, 2011. - 220 p.

14. Vykhrushch A. Methodology and Methods: Current Issues of Theory / A. Vykhrushch // Медична освіта. 2020. - № 2 (87). - C. 153-160.

15. Wolhuter C. C. Teacher Education to Meet TwentyFirst Century Society / C. C. Wolhuter // Teacher Education in Modern Era: Trends and Issues. University of Crete. Ministry of Education, Lifelong Learning and Religious Affairs. - Crete : Pedagogical Institute, 2011. - 308 p.

16. Wootten R. Characteristics of an Innovative Educator [Blog Post] [Electronic resource] / R. Wootten. - Retrieved May 28, 2014. - Access mode : http://teachamazing.com/7characteristics-of-an-innovative-educator].

17. Yelahina N. I. Motivation as a key component of teaching English for medical students / N. I. Yelahina, N. O. Fedchyshyn // Медична освіта. - 2019. - № 4 (84). C. 107-112.

Personality-word-society: materials of the VI International Scientific and Practical Conference. Retrieved from: http:// pws-conf.ru/ nauchnaya/lss-2006/371-formirovanielichnosti-v-sociume- /8175-psihologicheskaya-kulturaprepodavatelya-kak-vajnyyfaktor-formirovaniyauspeshnoy-lichnosti-studenta.html [in Russian]. 
2. Burova, M.V. Slagaemye imidzha pedagoga [Teacher's image components]. Retrieved from: http:// festival.1september.ru/articles/620720/ [in Russian].

3. Lihum, Yu.S. (2011). Yakist osvity i novitni texnolohiyi navchannya v konteksti intehraciyi v Yevropejskyj osvitnij prostir [Quality of education and the latest learning technologies in the context of integration into the European educational space]. Pedahohika i psyxolohiya - Pedagogy and Psychology [in Ukrainian].

4. Vykhrushch, A.V., Klishch, I.M., \& Fedchyshyn, N.O. (2017). Yakist vyshhoyi medychnoyi osvity (do 60-ty richchya TDMU) [Quality of higher medical education (to the 60th anniversary of TSMU)]. Ternopil: TDMU [in Ukrainian].

5. Vykhrushch, A.V., Yelahina, N.I., \& Klishch, H.I. (2016). Yakist universytetskoyi osvity: aktualni pytannya teoriyi $i$ praktyky [Quality of university education]. Ternopil: TNEU [in Ukrainian].

6. Aitken, J. (2014). The Capable Teacher, Competency Framework for Teachers of English for Academic Purposes. Retrieved from: http://www.baleap.org.uk/media/uploads/ pdfs/teap-competency-framework.pdf.

7. Berns, R.G., \& Erickson, P.M. (2014). Contextual Teaching and Learning: Preparing Students for the New Economy. The Highlight Zone: Research@Work. Retrieved from: www.cord.org.

8. Cockrell, K.S., \& Hughes, J.A. (2000). A Context for Learning: Collaborative Groups in the Problem-Based Learning Environment. The Review of Higher Education, 357.

9. Fedchyshyn, N.O., \& Yelahina, N.I. (2020). Peculiarities of future teacher's training at the higher educational establishment. Medychna osvita - Medical Education, 1(86), 11-15.

10. Fedchyshyn, N.O. (2020). Quality of higher medical education in Germany: realities and pecualiarities. Human studies: series of Pedagogy, 11/43, 103-114.

11. Palmer, P.J. (2007). The Courage to Teach: Exploring the Inner Landscape of a Teacher's Life, 10th anniversary edition. Retrieved from: www.wou.edu/ girodm/library/ palmer.pdf.

12. Prokop, I.A. (2017). The use of English professional texts-related exercise set for developing communicative competence of medical students. Medychna osvita-Medical Education, 4, 101-106.

13. Richards, J.C. (2011). Competence and Performance in Language Teaching. New York, NY: Cambridge University Press.

14. Vykhrushch, A. (2020). Methodology and Methods: Current Issues of Theory. Medychna osvita - Medical Education, 2 (87),153-160.

15. Wolhuter, C.C. (2011). Teacher Education to Meet Twenty-First Century Society. Teacher Education in Modern Era: Trends and Issues. University of Crete. Ministry of Education, Lifelong Learning and Religious Affairs. Crete: Pedagogical Institute.

16. Wootten, R. (2014). Characteristics of an Innovative Educator [Blog Post]. Retrieved from: http://teachamazing. com/7-characteristics-of-an-innovative-educator].

17. Yelahina, N.I., \& Fedchyshyn, N.O. (2019). Motivation as a key component of teaching English for medical students. Medychna osvita - Medical Education, 4(84), 107-112. 